\title{
TOWARDS AN IMPROVED PROCESS FOR DEVELOPING NEW PRODUCTS IN THE SOUTH AFRICAN DEFENCE INDUSTRY.
}

\author{
Mercer J. Potgieter and Herman Steyn \\ Department of Engineering and Technology Management \\ University of Pretoria \\ Pretoria, 0002, South Africa
}

\begin{abstract}
The purpose of this paper is to propose a single New Product Development (NPD) process for the Departmental Acquisition and Procurement Division (DAPD), Armscor and the South African Defence Industry. It examines the success factors and measures that contribute to the probability of success of NPD ventures. The NPD processes are grouped in three categories: information transfer, phased product development and integrated product development.
\end{abstract}

NPD processes currently applied in the Department of Defence (DoD) of the United Kingdom (UK), United States of America (USA) and South Africa are examined and evaluated against research findings on success factors for NPD. These NPD processes were taken into account in developing the proposed process.

Opsomming: Die doel van die artikel is om ' $\mathrm{n}$ enkele Nuwe Produk Ontwikkeling (NPO) proses vir die Departementele Aanskaffing en Verkryging Afdeling, Krygkor en die Suid-Afrikaanse Krygstuig Industrie voor te stel. Die suksesfaktore en metings wat mag bydra tot die waarskynlikheid van die sukses van die NPO onderneming word ondersoek. Die NPO prosesse word gegroepeer in drie kategorieë nl. inligting oordrag, gefasseerde produkontwikkeling en geïntegreerde produkontwikkeling .

Die NPO prosesse wat tans toegepas word deur die Departemente van Verdediging van die Verenigde Koninkryk, Verenigde State van Amerika en Suid-Afrika word ondersoek en ge-evalueer teen navorsing wat NPO sukses faktore identifiseer. Hierdie prosesse is in ag geneen by die ontwikkeling van die voorgestelde proses.

\section{Introduction}

Why a new formal NPD process?

Three reasons could be identified for a new formal NPD process. Firstly, acquisition is an extension of the National Security Policy process [1] and NPD is a sub-set of the acquisition process. The acceptance of Resolution 435 of the United Nations by South Africa as well as the change in the political environment in South Africa after 1990 had a major impact on the threat scenario of the South Africa. Defence must now be planned for a new era in a rapidly changing world [2].

Secondly, research [3][4][5] on NPD processes indicates that a formal process contributes substantially to the probability of success of NPD ventures.

Thirdly, NPD is a means of establishing superiority in a very competitive and dynamic environment [6][7]. The political changes in the new South Africa also brought new challenges to the local business environment. It opened the South African economy to competition from abroad and forced managers to revisit their approaches of doing business. Armscor is not excluded from this dynamic environment and must be flexible in its policies, processes and practices to accommodate this new situation. The political changes in South Africa created the opportunity of acquiring products on the international market. The once lucrative (and to a certain extent wasteful) defence acquisition business is faced with drastic curtailment of expenses. 


\section{A formal NPD process exist.s. Why change it?}

To answer this question. one needs to investigate the following issues:

1. How is success defined within NPD ventures?

2. What are the factors that contribute to success in NPD ventures?

3. How is success measured in NPD ventures?

4. What processes exist in the commercial environment that might serve as a benchmark for the development of a new NPD process?

5. What are the processes used in the DoD of the UK and the USA as well as in other European countries? What lessons can be learned from these?

The current NPD process is compared with the criteria for successful NPD. A single NPD Process for the DAPD, Armscor and the Defence Industry of SA that addresses the deficiencies in the current process, is proposed. The proposed process conforms to the characteristics of capability, flexibility, affordability, time efficiency and ease of application.

The following research methodology was applied:

1. A literature study was conducted on publications relating to NPD. The definition of success, success factors and success measures in NPD ventures received special attention.

2. The processes found in the literature were categorised in the following models:

- Information Transfer Model

- Phased Development Model

- Integrated Development Model

3. The NPD processes followed in the UK, USA were evaluated, and compared to the NPD processes used in literature.

4. The present NPD process applied in the DAPD, Armscor and Defence Industry was evaluated and compared to the NPD processes found in literature.

5. A model to be applied by the DAPD and Armscor is suggested based on the above findings.

\section{Success Factors and Measures in NPD Ventures}

\section{What is success?}

Cooper [8] defines success as "the degree to which a product exceeds (or falls short of) the minimum acceptable profitability for the type of investment". Crawford [9] argues that the solution to the problem of defining success may be found in the generally worded terms of "met company expectations". Mansfield [10] used the following criterion in his studies on failure rates: "To be successful a product has to produce profit greater than the alternatives then available."

The definition of success will differ from one project to another, from one project phase to another, from one stakeholder to another and from one management level to another.

\section{What are the success factors and measures?}

Various researchers have conducted studies in this field. Two studies conducted by Montoya-Weiss and Calantone [4], and Brown and Eisenhardt [5] summarise much of the research. Tables 1 and 2 list the success factors [4] and measures [11] at project level respectively. Tables 3 and 4 list the success factors [12] and measures [11] at company level respectively.

The success factors listed are the most significant factors found in literature. It must be recognised that:

1. Common factors of success exist.

2. The importance of the factors differs from country to country.

3. Factors differ at project and company level.

4. The success factors and measures will also differ between NPD process phases. 
Table 1: Project Level Success Factors [4]

\begin{tabular}{||l|}
\hline Strategic Factors \\
\hline Product Advantage \\
\hline Marketing Stralegy: \\
\hline Technology Synergy \\
\hline Strategy \\
\hline Company Resources \\
\hline Market Environment Factors \\
\hline Market Polential \\
\hline Market Competitiveness \\
\hline Environment \\
\hline Development Process Factors \\
\hline Protocol \\
\hline Proficiency of pre-development activities \\
\hline Proficiency of market-related activities \\
\hline Proficiency of technological activities \\
\hline Top management support, control \& skills \\
\hline Speed to market \\
\hline Costs \\
\hline Financial/Business analysis \\
\hline Organisational Factors \\
\hline Imternal/External communication \\
\hline Organisational factors \\
\hline
\end{tabular}

Table 3: Company Level Success Factors [12]

High-quality new product process

Clear and well-communicated new product strategy for the company

Adequate resources for new products

Commitment of senior management

Entrepreneurial climate for product innovation

Accountability of senior management

Strategic focus and synergy

High-quality development teams

Cross-functional teams
Table 2: Project Level Success Measures [11]

\begin{tabular}{|l|}
\hline Customer based Measures \\
\hline Customer Sanisfaction \\
\hline Customer. Acceptance \\
\hline Market share goals \\
\hline Revenue goals \\
\hline Revenue growth goals \\
\hline Unit volume goals \\
\hline Number of customers \\
\hline Financial Mcasures \\
\hline Met profit goals \\
\hline Met margin goals \\
\hline Internal Rate of Return (IRR) or Return On Investment (ROI) \\
\hline Break-event time \\
\hline Technical performance Measures \\
\hline Competitive advantage \\
\hline Met performance specifications \\
\hline Speed to marker \\
\hline Costs \\
\hline Met quality specifications \\
\hline Launch on time \\
\hline Innovativeness \\
\hline \\
\hline
\end{tabular}

Cross- functional teans

Table 4: Company Level Success Measures [11]

\begin{tabular}{|l|}
\hline Development programme ROI \\
\hline New products fit business strategy \\
\hline Success/failure rate \\
\hline$\%$ profits trom new products \\
\hline$\%$ sales from new products \\
\hline Programme hit 5-year objectives \\
\hline Products lead to future opportunities \\
\hline Overall programme success \\
\hline$\%$ sales under patent protection \\
\hline$\%$ profits under patent protection \\
\hline
\end{tabular}

Therefore, in designing a new NPD process, it is important that one understands the factors influencing the process and knows how to measure success. Understanding these factors will enable the designer of the new NPD process to incorporate the factors implicitly and explicitly in the new process. The environment, strategic intent and requirements of each of the stakeholders might differ and might therefore influence the applicable success factors and their measures.

\section{NPD Process - Theory and Known Practices}

Time to market has become an important competitive factor. Various studies to accelerate the NPD process have been conducted, amongst others by Millson et al [13], Gold [14] and Cordero [15]. Much of the research focus has been on the NPD process and can be divided into three categories:

1. Information Transfer Model

2. Phased Development Model

3. Integrated Development Model

Whatever approach is selected, the process is not the only element in the equation to find the solution to success within NPD ventures. 
Clark and Fujimoto [16] Gaynor [17], and Vroom [18] view the NPD process as a continuous transfer of information from one activity to the next.

Considering the information process [19] and the application thereof, it is easily understood why delays occur in the NPD process: Unless the personnel involved in the development process have knowledge of the process, of the technology involved, of the needs of the market, the project and company strategy, etc. the transfer of information could be time-consuming. This will ultimately have an impact on the success of the NPD venture. Integrated project teams is a management approach that can positively contribute to the successful transfer of information from one activity to the next.

\section{Phased Development}

The notion of phased development originated from the NASA Phased Programme Planning model and is known by various names e.g. structured development process, product delivery process and stage-gate [20].

Phased development is characterised by a number of project phases, each ending in a gate. The gate serves as a formalised decision point in the development process where certain criteria must be met before continuing onto the next phase.

Dean and Susman [21] suggest that this sequential approach of 'throwing the product over the wall', from design to manufacture, is no longer acceptable. Takeuchi and Nonaka [22] compare the 'traditional' phased or serial approach with a relay race where the baton is passed on from one functional department to the next.

Figure 1 depicts the third generation stage-gate model of Cooper [20]. Cooper's model shows overlapping stages and gates recognising the possibility that informed overlapping between stages would be to the benefit of the process.

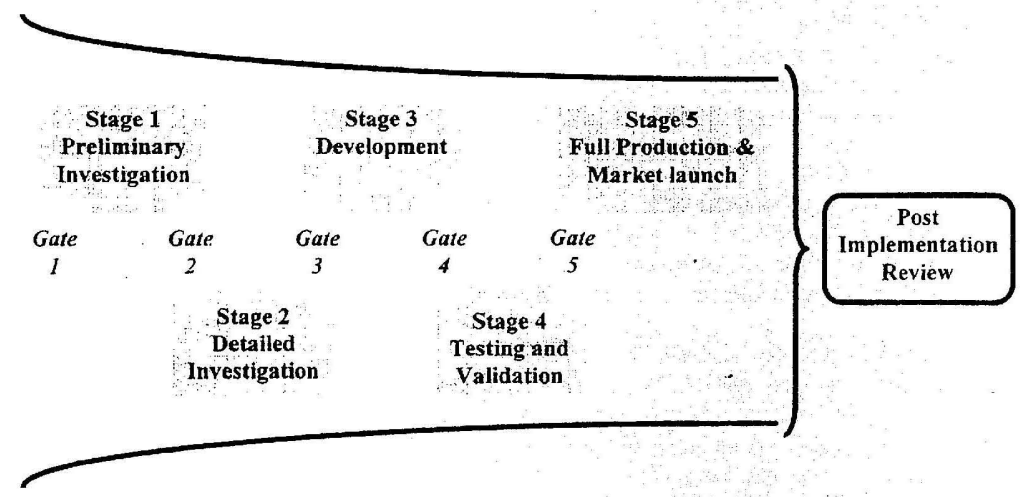

Figure 1: Third Generation Stage-Gate NPD Process [20]

The phased process established discipline within NPD, which was originally characterised by a haphazard approach that was time-consuming and costly, delivering products that barely conformed to customer requirements and were of low quality. 
Integrated Product Development (IPD) or Integrated Product and Process Development (IPPD) (Figure 2) has become the apparent solution to the need for reduced time to market, as well as for improved quality and affordability.

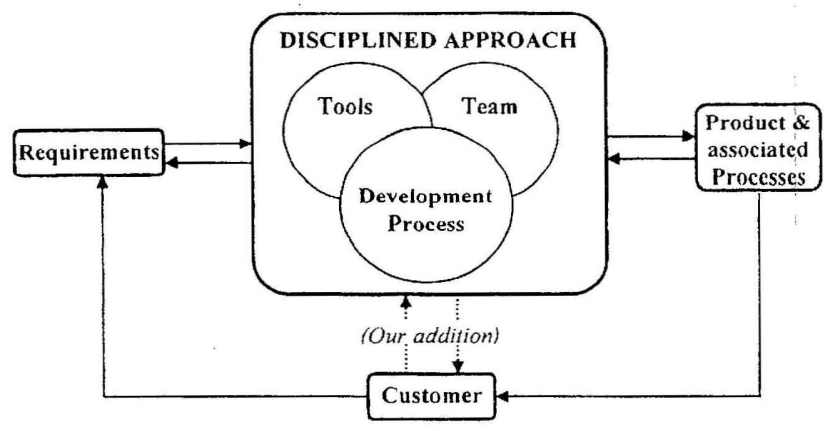

\section{Figure 2: Generic IPPD Iterative Process adapted from [23]}

Based on the research of Ehrlenspiel [24], Andreasen and Hein [25], Vajna and Burchardt [26], IPD is defined as: "A human-centred procedure for developing competitive products or services of high quality, within a reasonable amount of time, and with an excellent price-performance ratio. IPD describes the integrated application of holistic and multi-disciplinary methods, organisation forms, and both manual and computer-supported tools with minimised and sustainable use of production factors and resources."

There is therefore support in literature for the notion that NPD should be managed as a continuous flow of information instead of as discrete intermediate products passed on from one phase to the next. The challenge, however, lies in managing the flow of information, involving empowered multi-functional teams and selecting the appropriate techniques and methods during each phase of the NPD cycle.

Changes in the IPPD approach occur early at low cost compared to the Serial approach where changes occur late and at high cost.

\section{NPD Processes in Selected Overseas Acquisition Agencies}

The changes in the acquisition process of defence materiel in the DoD of the UK and USA are discussed under SMART Procurement (in the UK) and IPPD (in the USA).

\section{SMART Procurement - UK}

The Smart Procurement Initiative (SPI) was launched as part of the UK Strategic Defence Review in July 1997 [27].

The aim of Smart Procurement is "to enhance defence capability by acquiring and supporting equipment more effectively in terms of time, cost and performance". 
The "Federal Acquisition Streamlining Act of 1994" initiated the reform process in the DoD of the USA [32]. The mandate concluded that the "DoD must reducc the cost of the acquisition process by the elimination of activities that, ...., are not necessary or cost effective in today's environment".

The DoD defines IPPD as:

"A management technique that simultaneously integrates all essential acquisition activities, starting with requirements definition through production, fielding/deployment and operational support through the use of multidisciplinary teams to optimise the design, manufacturing and supportability processes."

In summary, the common factors identified in the reformed acquisition processes of not only the UK and the USA but also of other European countries are:

1. Reduction in the cost of acquisition

2. Reduction in the time to the delivery of systems

3. Improvement in performance and quality

4. Integrated project teams

5. Application of the System Engineering process through the NPD cycle

6. Customer focus

7. System approach in the development of the solution

8. Effective and efficient communication of applicable information throughout the NPD cycle.

Performance against these factors would only be realised through the disciplined application of sound engineering and management principles.

Table 5 identifies the success factors present in the new NPD process of the DoD of the UK and USA at project and management level.

\section{The Current and Proposed NPD Process}

\section{The Current NPD Process}

The current NPD process as applicable at Armscor is defined in the Armscor policy KB1000 [28]. The phased development process is depicted in Figure 3.

The following deficiencies can be identified in the process:

1. The separation of the user requirement statement development from the NPD cycle.

2. The separation of the decision-making processes in the Armscor, DAPD and user environments.

3. The low level of involvement of the end-user in the NPD cycle.

4. The early approval of the total programme funds.

5. The number of milestones and the involvement of the DAPD and the user in their approval.

6. The transfer of information from one phase to the next.

7. The late involvement of the supplier in the NPD cycle.

8. The time-consuming approval processes in the Armscor and DAPD/user environment.

9. The lack of empowerment of the programme manager and the DAPD representative.

10. The availability of sufficient funds in the important and high-impact initial phases.

11. The involvement and commitment of the management of Armscor and the DAPD/user.

12. The lack of team structure, especially from the supporting departments in Armscor.

The challenge is to find a solution to the above deficiencies. It will require the involvement and the undivided and sustained support and commitment of the management of Armscor and the DAPD. Table 5 identifies the success factors present in the current NPD process at project and management level. 


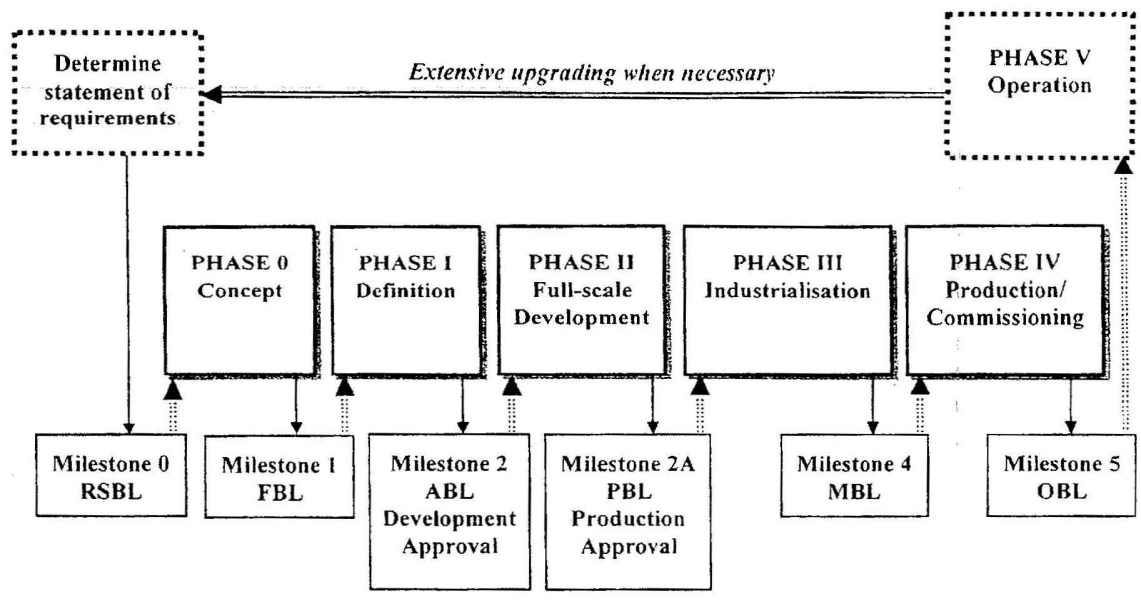

Figure 3: The Current NPD Process: Phases and Milestones [28]

\section{The Proposed Acquisition Process}

The proposed process should take into account the fact that the development of new systems in South Africa would probably be something of the past. The focus of the process must therefore be on the "fuzzy front end" (phases 1 and 2). It is during these phases that the requirements of the enduser are identified, defined and validated. These phases also determine the extent of the financial commitment for the future.

The process must accommodate incremental capability improvements, technology insertions and life extensions. The capability of managing and implementing these changes as well as managing the through-life support of the product system should exist within the local industry [29].

Figure 4 depicts the proposed new process. The process is a phased process but, as with the current process, overlaps between the phases are possible and should be managed as such to reduce NPD cycle time.

The proposed process differs from the current process in the following:

1. A single NPD process, applicable to the DAPD and Armscor, is established.

2. The identification and validation of the requirements of the end-user are combined into one phase and forms part of the NPD cycle.

3. The concept of "soft" and "hard" baselines is applied, with milestone 2 as the most important baseline for investment in the acquisition of the defined requirement to bridge the capability gap.

4. Full-scale development and industrialisation is combined. During this phase the process selected to produce the product will be part of the evaluation process. The development of the product is only complete when the product and the process that produces the product are validated.

5. The support and commitment of the management of the DAPD and Armscor is an integral element of the acquisition process throughout the phases without interference (versa vie involvement). This implies those resources such as personnel, funds, equipment, management and design tools should be made available to accomplish the programme objectives.

6. Integrated product and process development should be applied in every phase of the NPD cycle. 
The above goals are excellent objectives to strive for in the establishment of a NPD process.

The proposal of a new process is only the first step in the establishment of the new acquisition process. Bessant and Francis [30] identified six pre-conditions for successfully implementing a new or improved NPD process:

1. A clear understanding of the process to be followed. Criteria for cach phase and milestone should be shared with participants and clearly understood - no surprises.

2. Involvement of management with their support - championing the change and making the resources available.

3. Roles and responsibilities within the process should be identified and communicated.

4. Balanced involvement of upstream and downstream participants alleviating the unduly restriction of the process.

5. Shared objectives and supportive of the company's strengths and strategic focus.

6. A flexible process to cope with different types of projects.

This research shows that a flexible process, capable of accommodating different project types, robust in managing risks, easily understood and applied by all, and that enjoys the commitment of management, has the best chance of surviving.

\section{Conclusions}

The following conclusions are reached, based on the questions asked at the outset of the research:

1. The product development process must allow for flexibility and contain the success factors and measures identified.

2. The NPD process is more than just the NPD cycle. Numerous supporting processes are necessary for the successful realisation of a product system.

3. The present NPD process, as applied in the DAPD and Armscor, is inadequate to satisfy the challenges of the new South Africa.

4. A new process incorporating the lessons learned from the commercial environment and the current processes in the UK, USA and other countries must be developed and implemented.

\section{Recommendations}

It is recommended that:

1. The current approval processes should be revised and integrated. The delegation of powers to lower levels should be addressed and some levels in the approval process should be removed.

2. The drafting of the final budget for a programme/project should be postponed to such a stage where realistic budgeting figures could be submitted for approval by higher authorities.

3. The appointment of programme managers, members of Integrated Project Teams (IPTs) and the framework of reference of the IPTs be formalised within Armscor.

4. The responsibilities and level of authority of the programme manager and the representative of the DAPD be formalised within a framework of reference.

5. The NPD cycle should take cognisance of the research and findings in the commercial environment.

6. Training of personnel should be managed as a strategic objective of Armscor and the DAPD. 
Table 5: Conformance to Programme/Project level Success Factors in Selected Defence Acquisition Agencies

\begin{tabular}{|ccc|c|c|c|}
\hline NPD Processes in selected Defence Acquisition Agencies & $\begin{array}{c}\text { SMART } \\
\text { (UK) }\end{array}$ & $\begin{array}{c}\text { IPPD } \\
\text { (USA) }\end{array}$ & $\begin{array}{c}\text { KB1000 } \\
\text { (SA) }\end{array}$ & $\begin{array}{c}\text { PROPOSED } \\
\text { (SA) }\end{array}$ \\
\hline
\end{tabular}

Strategic Factors

Success Factors at Programme/Project Level

\begin{tabular}{|l}
\hline Product Advantage \\
\hline Marketing Strategy \\
\hline Technological Synergy \\
\hline Strategy \\
\hline Company Resources \\
\hline
\end{tabular}

\section{Market Environment Factors}

\begin{tabular}{|l|c|c|c|c|}
\hline Market Potential & $\mathrm{Y}$ & $\mathrm{Y}$ & $\mathrm{Y}$ & $\mathrm{Y}$ \\
\hline Market Competitiveness & $\mathrm{Y}$ & $\mathrm{Y}$ & $\mathrm{Y}$ & $\mathrm{Y}$ \\
\hline Environment & $\mathrm{Y}$ & $\mathrm{Y}$ & $\mathrm{Y}$ & $\mathrm{Y}$ \\
\hline
\end{tabular}

Development Process Factors

\begin{tabular}{|c|c|c|c|c|}
\hline Protocol & $Y$ & $\mathrm{Y}$ & $\Xi$ & $\mathrm{Y}$ \\
\hline Proficiency of pre-development activities & $\mathrm{Y}$ & $\Xi$ & $\Xi$ & $\bar{Y}$ \\
\hline Proficiency of market related activities & $\mathrm{Y}$ & $\mathrm{Y}$ & $\Xi$ & Y \\
\hline Proficiency of technological activities & $\mathrm{Y}$ & $\mathrm{Y}$ & $\mathrm{Y}$ & $\mathrm{Y}$ \\
\hline Top management support, control \& skills & $\mathrm{Y}$ & $\mathrm{Y}$ & $\Xi$ & $\mathrm{Y}$ \\
\hline Speed to market & $\mathrm{Y}$ & $\mathrm{Y}$ & $\Xi$ & $\bar{Y}$ \\
\hline Costs & $\mathrm{Y}$ & $\mathrm{Y}$ & $\Xi$ & $\mathrm{Y}$ \\
\hline Financial/Business analysis & $\mathrm{Y}$ & $\mathrm{Y}$ & $\Xi$ & $\bar{Y}$ \\
\hline \multicolumn{5}{|l|}{ Organisational Factors } \\
\hline Internal/External communication & $Y$ & $\mathrm{Y}$ & $\Xi$ & $\mathrm{Y}$ \\
\hline Organisational factors & $Y$ & $\mathrm{Y}$ & $\Xi$ & $\mathrm{Y}$ \\
\hline \multicolumn{5}{|c|}{ Success Factors at Company Level } \\
\hline High-quality new product process & Y & Y & $\Xi$ & Y \\
\hline $\begin{array}{l}\text { Clear and well communicated new product strategv for the } \\
\text { company }\end{array}$ & $\mathrm{Y}$ & $\mathrm{Y}$ & $\Xi$ & $\Xi$ \\
\hline Adequate resources for new products & $\bar{Y}$ & $\mathrm{Y}$ & $\Xi$ & $\Xi$ \\
\hline Commitment of senior management & $\mathrm{Y}$ & $\mathrm{Y}$ & $\Xi$ & $\Xi$ \\
\hline Entrepreneurial climate for product innovation & $\mathrm{Y}$ & $\mathrm{Y}$ & $\Xi$ & $\Xi$ \\
\hline Accountability of senior management & $\mathrm{Y}$ & $\mathrm{Y}$ & $\Xi$ & $\Xi$ \\
\hline Strategic focus and synergy & $\mathrm{Y}$ & $\mathrm{Y}$ & $\Xi$ & $\Xi$ \\
\hline High-quality development teams & $\mathrm{Y}$ & $\mathrm{Y}$ & $\Xi$ & $\Xi$ \\
\hline Cross-functional team. & $\mathrm{Y}$ & $\mathrm{Y}$ & $\Xi$ & $\mathrm{Y}$ \\
\hline
\end{tabular}

Key: $\mathrm{Y}=$ conformance $\quad \Xi=$ non-conformance 


\section{References}

[1] McCard, Harold, K., "Research and Development Strategies in the United States Air Force: Aerospace Challenges and Missions in the 1990's", The International Security Studies Programme, The Fletcher School of Law and Diplomacy, Tufts University, 3-4 April 1991.

[2] Aspin, L. and Dickinson, W., "Defense for the New Era", Brassey's (US) Inc., Washinton, DC, 1992.

[3] Cooper, Robert G., Kleinschmidt, Elko J., "Benchmarking the Firm's Critical Success Factors in New Product Development", Journal of Product Innovation Management, 12: 374-391, 1995.

[4] Montoya-Weis, Mitzi M., Calantone, Roger, "Determinants of New Product Performance: A Review and Meta-analysis", Journal of Product Innovation Management, 11: 397-417, 1994.

[5] Brown, Shona 1., Eisenhardt, Kathleen M., "Product Management: Past Research, Present Findings, and Future Directions", Academy of Management Review, Vol. 20, No. 2, 343-378, 1995.

[6] Porter, M. E., "Competitive Advantage: Creating and Sustaining Superior Performance", The Free Press, New York, 1985.

[7] De Bono, Edward, "Sur/petition - Going beyond Competition", HarperCollins Publisher, London, 1993.

[8] Cooper, Robert G., "New Product Success in Industrial Firms", Industrial Marketing Management, pg. 215-223, 11, 1982.

[9]. Crawford, C. Merle, "New Product Failure Rates - Facts and Fallacies", Research • Technology Management, September 1979.

[10] Mansfield, Edwin, Wagner, Samuel, "Organizational and Strategic Factors Associated with Probabilities of Success in Industrial R\&D", Journal of Business, pg. 179-198, April 1979.

[11] Griffin, Abbie, Page, Albert L., "PDMA Success Measurement Project: Recommended Measures for Product Development Success and Failure", Journal of Product Innovation Management, 13: 478-496, 1996.

[12] Cooper, Robert G., Kleinschmidt, Elko J., "Winning Business in Product Development: The Critical Success Factors", Research - Technology Management, July - August 1996.

[13] Millson, Murray R., Raj, S.P., Wilemon, David, "A Study of Major Approaches for Accelerating New Product Development", Journal of Product Innovation Management, 9: 53$69,1992$.

[14] Gold, Bela, "Approaches to Accelerating Product and Process Development", Journal of Product Innovation Management, 4: 81-88, 1987.

[15] Cordero, Rene, "Managing for Speed to avoid Product Obsolescence: A Survey of Techniques", Journal of Product Innovation, 8: 283-294, 1991.

[16] Clark, K. B. and Fujimoto, T., "Product Development Performances: Strategy, Organization, and Management in the World Auto Industry", Harvard Business School Press, Boston, Massachusetts, 1991.

[17] Gaynor, Gerard H., "Exploiting Product Cycle Time: Integrating Technologies, Products, and Markets", EMR, Spring 1993.

[18] Vroom, R.W., "A Metamodel for the Product Development Process", httpllwww.io.tudelft.nl/research/tpi/poster4.html, February 1994.

[19] Duursema, W.C., "Information the Power of Thinking: A Social Conceptual Approach", ProAct Business Consultants, Pretoria, 1995.

[20] Cooper, Robert G., "Overhauling the New Product Process", Industrial Marketing Management, 25: 465-482, 1996.

[21] Dean, J.W., Susman, G.I., "Organizing for manufacturable design”, Harvard Business Review, pg. 28-32, January-February 1989.

[22] Takeuchi, H., Nonaka, I., "The new New Product Development game", Harvard Business Review, pg. 137-146, January-February 1986.

[23] "Reengineering the Acquisition Oversight and Review Process", USD(A\&T), April 1995. 
[24] Ehrlenspiel, K., "Integrierte Produktentwicklung", Carl Hanser Verlag, München, 1995.

[25] Andreasen, M.M., Hein, L., "Integrated Product Development", Springer-Verlag, Berlin, 1987.

[26] Vajna, S., Burchardt, C., "Integrierte Produktentwicklung", Conference Report, 21, Kolloquium Konstruktiontechnik, Magdeburg, Germany, 1997.

[27] Webb, Simon (Team Leader), "Smart Procurement Initiative", http//www.adobe.com/prodindex/readstep.html, edition 3, 4 December 1998.

[28] "Armscor Policy: Acquisition", KB 1000, 1 May 1995.

[29] Punt, L.J., "Industry Operational Vehicle Technology Strategy", No. KT440930-004, issue 1, 25 July 1999. (to be approved)

[30] Bessant, John Francis, David, "Implementing the New Product Development Process", Technovation, vol. 17, no. 4, 189-197, 1997. 